\title{
Plant Bio regulators and Chemicals Exogenous Application Impact on Flowering and Yield Attributes of Mango (Mangifera indica L) cv. Banganpalli
}

\author{
G. Vijay Krishna ${ }^{1 *}$, A. Bhagwan², A. Kiran Kumar², A. Girwani ${ }^{3}$, \\ M. Sreedhar ${ }^{4}$, S. Narendar Reddy ${ }^{5}$ and M. Hanuman Nayak ${ }^{6}$ \\ ${ }^{1}$ Horticultural Research Station, Aswaraopet, SKLTSHU, Telangana, India \\ ${ }^{2}$ Fruit Research Station, Sangareddy, SKLTSHU, Telangana, India \\ ${ }^{3}$ College of Horticulture, Mojerla, Mahabubnagar, SKLTSHU, Telangana, India \\ ${ }^{4}$ Department of crop Physiology, ${ }^{5}$ Department of plant breeding, College of Agriculture, \\ Hyderabad Telangana, India \\ ${ }^{6}$ Vegetables Research Station, Hyderabad, SKLTSHU, Telangana, India \\ *Corresponding author
}

\section{A B S T R A C T}

\section{Keywords}

Banganpalli, Paclobutrazol, Salicylic acid, CPPU, Boron, Percent flowering

Article Info

Accepted:

22 June 2020

Available Online:

10 July 2020
Field experiment was conducted during 2015-16 at Fruit research station, Sangareddy to study the exogenous application effect of flower enhancing plant bio regulators and fruit set improving chemicals on flowering and yield of mango cv. Banganpalli. Trees applied with paclobutrazol and other plant bio regulators (NAA and SA) were significantly increased the percent flowering compares to control trees. Paclobutrazol alone and in combination with spermidine treatment has recorded significantly maximum number of fruits per tree and yield (13.97\% and $41.54 \%$ over control) due to increase in fruit set and fruit retention. Among fruit set improving chemicals, CPPU has recorded maximum yield (11.85\% over control) due to increased fruit set. Among interactions, the combination of NAA and spermidine has increased yield up to $48.04 \%$ over control due to prolonged flowering by NAA and increased fruit set by spermidine. Maximum benefit cost ratio of 8.69 was recorded with NAA along with spermidine.

\section{Introduction}

Mango occupied an area of 2.26 million hectares with a production of 19.68 million tonnes in India (NHB, 2017). Telangana state is the fourth largest mango producing state of India and it occupies an area of 0.18 million hectares with a production of 1.68 million tonnes (NHB, 2017). In Telangana state the commercial cultivar is Banganpalli which occupies about 70 per cent of total mango cultivated area. There are several reasons for poor productivity in mango cv. Banganpalli in Telangana. Among them, poor and erratic flowering coupled with poor or nil fruit set in mango cv. Banganpalli is one of the major 
reasons for poor productivity. The flowering and fruit set in mango is majorly influenced by the temperature during flowering (Davenport, 2007). A night temperature of less than $15^{\circ} \mathrm{C}$ for $3-4$ weeks is necessary for mango to flower, a night temperature above $14^{\circ} \mathrm{C}$ is needed for proper fruit set (Davenport, 2003). The climatic changes especially temperature during flowering and fruit set period has been attributed to erratic flowering and poor fruit set in mango cv. Banganpalli (Bhagwan et al., 2011).

The mango productivity is largely controlled by climate, which invariably cannot be controlled and hence efforts have to be directed to modulate the mango phenology to suit unfavorable climatic conditions (Rajan et al., 2011). Under such circumstances modulation of vegetative growth, flowering, and fruit set by spraying of plant bio regulators and chemicals is the best alternative to mitigate or reduce the adverse climate effect on mango.

\section{Materials and Methods}

The Present investigation was carried out during 2015-16 at Fruit research station, Sangareddy, Telangana. Fifteen years old, well grown, uniform statured trees of mango cv. Banganpalli were selected for the experiment. Trees were spaced with $8 \mathrm{~m}$ and planted in square system. Paclobutrazol concentration was calculated based on the diameter of the tree, and applied @ $3 \mathrm{ml} \cdot \mathrm{m}^{-1}$ of canopy diameter. The required paclobutrazol was dissolved in 10 litre of water, applied as soil drench 120 days before bud break (Bhagwan et al., 2011). $80 \mathrm{mg}$ of NAA was dissolved in $50 \mathrm{ml}$ of ethanol and diluted it in 1 litres of water to get $80 \mathrm{ppm}$ of NAA. $100 \mathrm{mg}$ of SA was dissolved in $50 \mathrm{ml}$ of ethanol and diluted it in 1 litre of water to get $100 \mathrm{ppm}$ of SA. Ten litres of NAA 80 ppm solution was sprayed per tree 30 days before flowering (Davenport, 2007). Ten litres of SA 100 ppm solution was sprayed per tree 30 days before flowering (Ashok kumar and Reddy 2007).

$1.45 \mathrm{mg}$ of spermidine was dissolved in 1 litre of water to get $0.01 \mathrm{mM}$ of spermidine. 1.5 gm of boron $(20 \%)$ was dissolved in 1 litre of water to get $1.5 \mathrm{~g} .1-1$ of boron. $10 \mathrm{mg}$ of CPPU was dissolved in 1 litres of water to get $10 \mathrm{ppm}$ of CPPU. Fruit set improving chemicals (spermidine, spermine and boron) were sprayed at full bloom stage. The above chemicals and plant growth regulators were sprayed to observe the flowering; fruit set and yield of the trees by using of $\mathrm{BBCH}$ scale. The statistical design adopted was Factorial Randomised block design with 16 treatments which were replicated thrice. Data on percent flowering (flowering phenophases) and fruit set (fruit phenophases) was recorded by using mango BBCH scale (Rajan et al., 2011). The data was subjected to statistical analysis as per the procedure out lined by Panse and Sukhatme (1985).

\section{Results and Discussion}

\section{Flowering}

The results on percent flowering after application of different plant bio regulators and chemicals are presented in the table 1. The data revealed that there was significant difference among flower enhancing plant bio regulators application with respect to per cent flowering. Maximum flowering per cent was recorded in application of paclobutrazol $\left(\mathrm{B}_{1}\right)$ (69.16), which was on par with application of salicylic acid $\left(\mathrm{B}_{3}\right)(66.24)$ and NAA $\left(\mathrm{B}_{2}\right)$ (64.58). Minimum flowering per cent was recorded in untreated control $\left(\mathrm{B}_{0}\right)$ (50.83). Fruit set improving chemicals have sprayed during full bloom phase and hence, it might not have influenced on per cent flowering which were recorded before full bloom. 
However, any significant differences in flowering might have resulted from the factors other than fruit set improving chemical which were sprayed after the data recorded on per cent flowering. Paclobutrazol and other flower enhancing plant bio regulators were significantly increased the per cent flowering compared to control (Table 1). Gibberellins, a group of plant growth hormones were reported to be inhibitory to flowering (Kachru et al., 1971), in mango and the available evidence suggests the flower promoting effect of paclobutrazol in mango due to its anti-gibberellin activity (Quinlan and Richardson, 1984). Hence, in the present investigation the increase in the per cent $(\%)$ flowering of mango by paclobutrazol was due to its anti-gibberellin activity. Similar increase in per cent flowering by Paclobutrazol application was earlier reported by Bhagwan et al., (2014) in mango cv. Banganpalli, Srilatha and Reddy (2015) in mango cv. Raspuri and Babul Sarkar et al., (2016) in mango.

In the present investigation NAA was found to be significantly increased the per cent flowering in mango cv. Banganpalli when compared to control. Similarly increase in flowering with NAA spray was reported in mango cv. Succary Abiad (Wahdan et al., 2011), Vijay krishna et al., (2012) in mango cv. Banganpalli. NAA which is considered as flowering hormone in some crops (Moti Singh et al., 1987) might have increased the latent flowering factors in the mango and resulted in overall increase in flowering in mango cv. Banganpalli when compared to control in the present investigation. SA spray has also significantly increased the per cent flowering in mango cv. Banganpalli in the present investigation when compared with the control (Table 1). Similar increase in per cent flowering by SA was earlier reported by Faisal Ahmed et al., (2014) in Keitte mango and Mandal et al., (2015) in mango cv.
Amrapali. The stimulatory effect of salicylic acid on growth, flowering and yield has been reported in annual crops under both short and long day periods (Kumar et al., 1999). Srilatha and Reddy (2015) concluded that the total phenolics and phenolic acids viz., salicylic acids, coumaric acids and 4-hydroxy benzoic acids were drastically increased during flowering phase of mango cv. Raspuri. Endogenous concentration levels of salicylic acid and other phenolic acids might be a reason for flower regulation in mango plants.

\section{Fruit set and yield parameters}

The results on fruit set per panicle (at 701 and 703 phenophases) after application of different flower enhancing plant bio regulators and fruit set improving chemicals are presented in the Table 2.

\section{At 701 phenophase}

The data presented in the table 2 , revealed that there was significant difference among flower enhancing plant bio regulators with respect to fruit set per panicle at 701 phenophase of mango. Maximum fruit set per panicle was recorded in application of salicylic acid $\left(\mathrm{B}_{3}\right)(9.15)$, which was on par with application of NAA $\left(\mathrm{B}_{2}\right)$ (8.96). Minimum fruit set per panicle observed in application of paclobutrazol $\left(\mathrm{B}_{1}\right)$ (8.34), which was at par with untreated control $\left(\mathrm{B}_{0}\right)$ (8.51).

Fruit set improving chemical treatments had significant influence on fruit set per panicle of mango. Maximum fruit set per panicle was recorded in application of spermidine $\left(\mathrm{F}_{1}\right)$ (9.38), which was on par with application of CPPU $\left(F_{3}\right)$ (8.99). Minimum fruit set per panicle was recorded in untreated control $\left(\mathrm{F}_{0}\right)$ (8.23), which was on par with application of boron $\left(\mathrm{F}_{2}\right)(8.36)$. 
Significant difference was observed in interaction effect between flower enhancing plant bio regulators and fruit set improving chemicals with respect to fruit set per panicle of mango. Maximum fruit set per panicle was recorded in application of salicylic acid along with CPPU application $\left(\mathrm{B}_{3} \mathrm{~F}_{3}\right)(9.83)$, which was on par with application of spermidine alone $\left(\mathrm{B}_{0} \mathrm{~F}_{1}\right)$ (9.76), paclobutrazol along with spermidine application $\left(\mathrm{B}_{1} \mathrm{~F}_{1}\right)(9.66)$, salicylic acid alone application $\left(\mathrm{B}_{3} \mathrm{~F}_{0}\right)$ (9.32), salicylic acid along with spermidine application $\left(\mathrm{B}_{3} \mathrm{~F}_{1}\right)$ (9.26), CPPU alone application $\left(\mathrm{B}_{0} \mathrm{~F}_{3}\right)(9.21)$, NAA alone application $\left(\mathrm{B}_{2} \mathrm{~F}_{0}\right)(9.05)$, NAA along with CPPU application $\left(\mathrm{B}_{2} \mathrm{~F}_{3}\right)(9.00)$, NAA along with boron application $\left(\mathrm{B}_{2} \mathrm{~F}_{2}\right)$ (8.95) and NAA along with spermidine application $\left(\mathrm{B}_{2} \mathrm{~F}_{1}\right)(8.84)$. Minimum fruit set per panicle was recorded in untreated control $\left(\mathrm{B}_{0} \mathrm{~F}_{0}\right)$ (7.13).

\section{At 703 phenophase}

The data presented in the table 2 revealed that there was significant difference among flower enhancing plant bio regulators with respect to fruit set per panicle at 703 phenophase of mango. Maximum fruit set per panicle was recorded in application of salicylic acid $\left(B_{3}\right)$ (3.74), which was on par with untreated control $\left(\mathrm{B}_{0}\right)$ (3.59) and application of NAA $\left(B_{2}\right)$ (3.41). Minimum fruit set per panicle observed in application of paclobutrazol $\left(\mathrm{B}_{1}\right)$ (3.21).

Fruit set improving chemical treatments had significant influence on fruit set per panicle of mango. Maximum fruit set per panicle was recorded in application of CPPU $\left(\mathrm{F}_{3}\right)$ (3.91), which was on par with application of spermidine $\left(\mathrm{F}_{1}\right)$ (3.81). Whereas minimum fruit set per panicle was recorded in boron $\left(\mathrm{F}_{2}\right)$ (3.18) which was on par with untreated control $\left(\mathrm{F}_{0}\right)$ (3.49). Significant difference was observed in interaction effect between flower enhancing plant bio regulators and fruit set improving chemicals with respect to fruit set per panicle of mango. Maximum fruit set per panicle was recorded in application of salicylic acid along with CPPU application $\left(\mathrm{B}_{3} \mathrm{~F}_{3}\right)$ (4.66), which was on par with application of spermidine alone $\left(\mathrm{B}_{0} \mathrm{~F}_{1}\right)(4.40)$ and with application of CPPU alone $\left(\mathrm{B}_{0} \mathrm{~F}_{3}\right)$ (4.33). Minimum fruit set per panicle was recorded in control $\left(\mathrm{B}_{0} \mathrm{~F}_{0}\right)(2.46)$.

SA and NAA treatments significantly increased the number of fruits per panicle at 703 phenophase compare to other treatment. The increase in panicle length with subsequent increase in total number of flowers per panicle compared to other treatments might have resulted in the increased fruit set per panicle in the trees treated with SA in the present investigation. Similar increase in fruit set per panicle with SA was earlier reported by Abdel razek et al., (2013) in mango cv. Hindi. The increase in the number of fruits per panicle with NAA treatment in the present investigation might be due to increase in time taken for 100 per cent flowering (Table 1) resulting in prolonged blooming period ultimately resulting in better pollination and fruit set (Vijay krishna et al., 2012). Similar results were earlier reported by Merwad et al., (2016) in mango cv. Aphonso and Shurhozenuo Naleo et al., (2018) in mango cv. Amrapali.

Among fruit set improving chemicals spermidine and CPPU significantly increased fruit set per panicle compare to other treatments. Polyamines like spermine and spermidine might have increased the number of fruits per panicle by improving the embryo development (Ponce et al., 2002), increase the viability of the ovule and prolonged pollination period (Crisosto et al., 1988) and increase in the pollen germination and pollen tube growth (Wolukau et al., 2004) in the present investigation. The increase in fruit set per panicle by application of spermidine was 
earlier reported by Vijay krishna et al., (2012) in mango cv. Banganpalli and Ravi venkanna babu et al., (2016) in Kesar mango. CPPU significantly increased number of fruits per panicle compare to other treatments. CPPU i.e Forchlorofenuronis a member of the synthetic cytokinin group with phenyl urea structure, is a strong inhibitor of cytokinin oxidation (Mok and Mok, 2001). CPPU is an effective and well- known PGR for stimulating cell division (Kim et al., 2006), which might be a reason for better fruit set under present investigation. Similar increase in fruit set per panicle was earlier reported by Pujari et al., (2016) in mango cv. Alphonso and Kulakarni et al., (2017) in Kesar mango.

Among interactions $\mathrm{SA}$ in combination with CPPU $\left(\mathrm{B}_{3} \mathrm{~F}_{3}\right)$ significantly increased the number of fruits per panicle compare to control and other treatments.

Increased panicle length which might have increased the total number of flowers per panicle (Abdel razek et al., 2013) compared to other treatments was responsible for increase in fruit set per panicle in trees treated with SA in the present investigation. CPPU is an effective and well- known PGR for stimulating cell division (Kim et al., 2006), which might be a reason for better fruit set with CPPU application compares to control (Pujari et al., 2016).

SA along with CPPU application, because of their fruit set improving properties might have caused increase in number of fruits per panicle synergistically compare to their individual application, control and other treatments. Similar synergistic effect in increasing the number of fruits per panicle was earlier reported by Fasil Ahmed et al., (2014), combination of SA along with turmeric extract increases number of fruits per panicle to their individual application in Keitte mango.
The results on total number of fruits per tree after the application of different flower enhancing plant bio regulators and fruit set improving chemicals are presented in the table 3. The data revealed that there is significant difference among flower enhancing plant bio regulators with respect to number of fruits per tree in mango. Maximum number of fruits was recorded in application of paclobutrazol $\left(\mathrm{B}_{1}\right)$ (182.16), followed by application of NAA $\left(\mathrm{B}_{2}\right)$ (169.57). Minimum number of fruits per tree was recorded with application of salicylic acid $\left(\mathrm{B}_{3}\right)$ (137.66), which was at par with untreated control $\left(\mathrm{B}_{0}\right)$ (143.33). Paclobutrazol have significantly increases number of fruits per tree compares to control and other treatments. Similar increase in number of fruit per tree with Paclobutrazol was earlier reported by Vijay krishna et al., (2012) in Banganpalli mango and Babul Sarkar et al., (2016) in mango cv. Amrapali. NAA also significanlty increased number of fruits per tree. Similar increase in number of fruit per tree was earlier reported by Kulakarni et al., (2017) in Kesar mango, Abd el-rhman et al., (2017) in mango cv. Hindi and Shurhozenuo Naleo et al., (2018) in Amrapali mango.

The increase in number of fruits per tree with paclobutrazol application (Table 3) in the present investigation might be due to significant increase in flowering percentage (Table 1). Similar correlation between intensity of flowering, perfect flowers and better fruit set and subsequent increase in total number of fruits per tree and yield was earlier reported by Vijay krishna et al., (2012) in Banganpalli mango and Shurhozenuo Naleo et al., (2018) in Amrapli mango.

Fruit set improving chemical treatments had significant influence on number of fruits per tree of mango. Maximum number of fruits was recorded in application of spermidine $\left(F_{1}\right)$ (171.33). Minimum number of fruits was 
recorded in untreated control $\left(\mathrm{F}_{0}\right)$ (148.16), which was on par with application of CPPU $\left(\mathrm{F}_{3}\right) \quad(156.24)$ and boron $\left(\mathrm{F}_{2}\right)$ (156.99). Spermidine significantly increased number of fruits per tree compared to control and other treatments. Similar increase in number of fruits per tree with Spermidine was earlier reported by Vijay krishna et al., (2012) in mango cv. Banganpalli, Ravi venkanna babu et al., (2016) in mango cv. Kesar and Dutta et al., (2018) in Himsagar mango.

The increase in number of fruits per tree by application of polyamines like spermidine and spermine may be due to improvement in embryo development (Ponce et al., 2002) and subsequent increase in viability of ovules and a prolonged pollination period (Crisosto et al., 1988). There is substantial evidence to support that ethylene is the main trigger in abscission process (Brown, 1997) and polyamines are considered as anti-ethylene substances (Apelbaum et al., 1981), being the likely competitors of precursors of ethylene (S-adenosyl methionine). Hence, exogenous application of polyamines has been reported to improve fruit retention in mango (Singh and Singh, 1995) by increase in number of fruit per panicle.

The interaction effect between flower enhancing plant bio regulators and fruit set improving chemicals on number of fruits per tree was significant. Maximum number of fruits per tree was recorded in NAA along with spermidine application $\left(\mathrm{B}_{2} \mathrm{~F}_{1}\right)$ (202.66), which was on par with application of paclobutrazol along with spermidine $\left(\mathrm{B}_{1} \mathrm{~F}_{1}\right)$ (200.00) and paclobutrazol along with boron application $\left(\mathrm{B}_{1} \mathrm{~F}_{2}\right) \quad$ (198.66). Minimum number of fruits per tree was recorded in salicylic acid along with boron application $\left(\mathrm{B}_{3} \mathrm{~F}_{2}\right)$ (131.00). NAA in combination with spermidine could able to increase the number of fruits per tree compare to control and other treatments (Table 3). NAA was found to increase the number of reproductive shoots per tree (Muhammad et al., 2010) and perfect flowers per panicle (Raj Kumar et al., 2007). Spermidine (polyamines) as earlier discussed cause for better fruit set by increasing the embryo development (Ponce et al., 2002), by increase the viability of ovules and prolonged pollination period (Crisosto et al., 1988) and increased the harvested fruits per tree by increasing the fruit retention, possibly by inhibiting endogenous ethylene biosynthesis, which is the known trigger in abscission (Brown, 1997). The flower enhancing ability of NAA and fruit set improving property of spermidine has synergistically increased in overall number of fruits harvested per tree when compared to their individual effect in the present investigation. Similar synergistic increase in number of fruits harvested per tree was earlier reported by Raj Kumar et al., (2006) with the application of paclobutrazol along with $\mathrm{Ca}\left(\mathrm{NO}_{3}\right)_{2}$ in mango cv. Baneshan. Baiea et al., (2015) with foliar spray of boric acid in combination with potash in Keitt Mango.

The changes in fruit weight (gm) of mango cv. Banganpalli sprayed with different flower enhancing plant bio regulators and fruit set improving chemicals are presented in the table 4. There was significant differences among flower enhancing plant bio regulators application with respect to fruit weight (gm) and maximum fruit weight was recorded with the application of salicylic acid $\left(\mathrm{B}_{3}\right)$ (347.74). Minimum fruit weight was recorded with application of NAA $\left(B_{2}\right)$ (326.96), which was at par with application of paclobutrazol $\left(\mathrm{B}_{1}\right)$ (327.07) and in untreated control $\left(\mathrm{B}_{0}\right)$ (329.16). SA could able to increase fruit weight compared to control and other treatments. It was earlier reported that SA application promotes cell division, cell enlargement and application of leaf area of treated plants (Hayat and Ahmad, 2007). According to the study of John et al., (2004) 
the positive effects of SA on growth and yield could be due to its interaction on other plant hormones. The increase in fruit weight with SA treatment in the present investigation (Table 4) might be due to alteration in the auxin, cytokinin and ABA balances. Similar increase in fruit growth and fruit weight was reported by Faissal Ahmed et al., 2014 in mango cv. Keitte and Mandal et al., 2015 in Amrapali mango.

There is significant difference in fruit weight among different fruit set improving chemical application. Maximum fruit weight was recorded in application of CPPU $\left(\mathrm{F}_{3}\right)$ (343.08), which was on par with spray of boron $\left(\mathrm{F}_{2}\right)$ (335.37). Minimum fruit weight was recorded in untreated control $\left(\mathrm{F}_{0}\right)$ (322.89), which was on par with application of spermidine $\left(\mathrm{F}_{1}\right)$ (329.60). Both CPPU and Boron significantly increased fruit weight compares to control. N- (2-Chloro-4-pyridyl)$\mathrm{N}$-Phenylurea (CPPU) is a synthetic cytokinin that can stimulate cell division and cell elongation in pear (Flaishman et al., 2001). Any increase in length, width and thickness of fruit brought a corresponding increase in weight of fruit (Kulakarni et al., 2017). The possible explanation for increase in fruit size and weight was also due to faster movement of simple sugars of fruit and involvement in cell expansion (Bramhachari et al., 1996). CPPU increases cell size and is also responsible for the production and transport of plant sugars that increases the weight of fruit (Singh et al., 1994). These reasons might be responsible for increase in fruit weight with CPPU application. Similar increase in fruit weight with CPPU was earlier reported by Kulakarni et al., (2017) in Kesar mango and Gattass et al., (2018) in Keitt mango trees. Boron could able to increase fruit weight by increase in cell division; cell enlargement and fruit volume resulted in increased fruit weight in mango cv. Alphonso (Sankar et al., 2013). The similar results were earlier reported by Sanna et al., (2005) in mango and Moawad et al., (2015) in mango cv. Succary.

The interaction effect on fruit weight between the application of flower enhancing plant bio regulators and fruit set improving chemicals was significant. Maximum fruit weight was recorded in application of salicylic acid along with boron $\left(\mathrm{B}_{3} \mathrm{~F}_{2}\right)$ (366.00), which was on par with application of paclobutrazol along with CPPU $\left(\mathrm{B}_{1} \mathrm{~F}_{3}\right)$ (362.41), salicylic acid along with spermidine $\left(\mathrm{B}_{3} \mathrm{~F}_{1}\right)$ (355.16), boron alone application alone application $\left(\mathrm{B}_{0} \mathrm{~F}_{2}\right)(350.33)$ and NAA along with CPPU application $\left(\mathrm{B}_{2} \mathrm{~F}_{3}\right)$ (347.83). Minimum fruit weight was recorded with application of Paclobutrazol along with boron $\left(\mathrm{B}_{1} \mathrm{~F}_{2}\right)$ (300.08). SA in combination with Boron could able to increase the fruit weight significantly compared to control and their individual application. SA and boron in the present investigation might have synergistically improved the fruit weight compared to their individual effects. Similar synergistic effect in increasing the fruit weight was earlier reported by and Faisal Ahmed et al., (2014) SA along with Turmeric extract in mango cv. Keitte, and Moawad et al., (2015) Boric acid in combination with Potassium silicate in Succary mango.

The results on yield per tree after the application of different flower enhancing plant bio regulators and fruit set improving chemicals are presented in the table 5. The data revealed that there is a significant difference in yield ( $\mathrm{kg}$ per tree) among different flower enhancing plant bio regulators. Maximum yield was recorded in application of paclobutrazol $\left(\mathrm{B}_{1}\right)$ (59.25), which was on par with application of NAA $\left(B_{2}\right)$ (55.45). Minimum yield was recorded in untreated control $\left(\mathrm{B}_{0}\right)$ (46.84), which was at par with application of salicylic acid $\left(\mathrm{B}_{3}\right)$ (47.73). Paclobutrazol and NAA significantly 
increase the yield per tree compared to control and other treatments. Both Paclobutrazol and NAA effectively increased per cent flowering (Table 1), Fruit set per panicle (Table 2) and number of fruits per tree (Table 3) which might have ultimately increases the yield under present investigation. The similar increase in yield with Paclobutrazol was earlier reported by Raj Kumar et al., (2007) in mango cv. Baneshan, Vijay krihna et al., (2012) in mango cv. Banganpalli, Srilatha and Reddy (2015) in Raspuri mango and Babul Sarker et al., (2016) in mango cv. Amrapali.

Table.1 Effect of flower enhancing plant bio regulators and fruit set improving chemicals on per cent flowering of mango cv. Banganpalli

\begin{tabular}{|c|c|c|c|c|c|}
\hline \multirow[t]{2}{*}{ Treatment } & \multicolumn{5}{|c|}{ Per cent flowering } \\
\hline & $B_{1}-\mathbf{P B Z}$ & $\mathbf{B}_{2}$-NAA & $\mathbf{B}_{\mathbf{3}}-\mathbf{S A}$ & $B_{0}$ - Control & Mean \\
\hline$F_{1}$ - Spermidine & 66.66 & 53.33 & 73.33 & 55.00 & 62.08 \\
\hline$F_{2}-$ Boron & 80.00 & 61.66 & 66.66 & 41.66 & 62.49 \\
\hline $\mathrm{F}_{3}-\mathrm{CPPU}$ & 58.33 & 73.33 & 58.33 & 50.00 & 59.99 \\
\hline $\mathbf{F}_{0}-$ Control & 71.66 & 70.00 & 66.66 & 56.66 & 66.24 \\
\hline \multirow[t]{2}{*}{ Mean } & 69.16a & $64.58 a$ & $66.24 a$ & $50.83 b$ & \\
\hline & \multicolumn{2}{|c|}{ F -Test } & S.Em \pm & \multicolumn{2}{|c|}{ CD at $(5 \%)$} \\
\hline Factor B & \multicolumn{2}{|c|}{$*$} & 3.250 & \multicolumn{2}{|c|}{9.534} \\
\hline Factor $\mathbf{F}$ & \multicolumn{2}{|c|}{$*$} & 3.250 & \multicolumn{2}{|c|}{ NS } \\
\hline $\mathbf{B} \times \mathbf{F}$ & \multicolumn{2}{|c|}{$*$} & 6.501 & \multicolumn{2}{|c|}{ NS } \\
\hline
\end{tabular}

Figures with same alphabets did not differ significantly.

$* *$ Significant at $(\mathrm{p}=0.01 \mathrm{LOS}),{ }^{*}$ Significant at $(\mathrm{p}=0.05 \mathrm{LOS})$, NS- Non Significant.

Values were compared with respective C.D values

Table.2 Effect of flower enhancing plant bio regulators and fruit set improving chemicals on number of fruits per panicle of mango cv. Banganpalli

\begin{tabular}{|c|c|c|c|c|c|c|c|c|c|c|}
\hline Treatme & \multicolumn{10}{|c|}{ Number of fruits per panicle } \\
\hline Days & \multicolumn{5}{|c|}{701 phenophase } & \multicolumn{5}{|c|}{703 phenophase } \\
\hline & $\mathbf{B}_{1}$ & $\mathbf{B}_{2}$ & $\mathbf{B}_{3}$ & $\mathbf{B}_{\mathbf{0}}$ & Mean & $\mathbf{B}_{1}$ & $\mathbf{B}_{2}$ & $\mathbf{B}_{3}$ & $\mathbf{B}_{\mathbf{0}}$ & Mean \\
\hline $\mathbf{F}_{1}$ & $9.66 a$ & $8.84 a$ & $9.26 \mathrm{a}$ & $9.76 a$ & 9.38a & $3.80 \mathrm{~b}$ & $3.20 b$ & $3.86 b$ & $4.40 \mathrm{a}$ & 3.81a \\
\hline $\mathbf{F}_{2}$ & $8.33 b$ & $8.95 a$ & $8.22 b$ & $7.95 b$ & $8.36 b$ & $2.93 \mathrm{c}$ & $3.06 \mathrm{c}$ & $3.53 b$ & $3.20 \mathrm{~b}$ & 3.18b \\
\hline $\mathbf{F}_{3}$ & $7.94 b$ & $9.00 \mathrm{a}$ & $9.83 a$ & $9.21 \mathrm{a}$ & $8.99 a$ & $3.13 c$ & $3.53 b$ & $4.66 a$ & $4.33 a$ & 3.91a \\
\hline $\mathbf{F}_{\mathbf{0}}$ & $7.45 b$ & $9.05 \mathrm{a}$ & $9.32 \mathrm{a}$ & $7.13 c$ & $8.23 b$ & $3.00 \mathrm{c}$ & $3.86 \mathrm{~b}$ & $2.93 c$ & $2.46 \mathrm{c}$ & 3.49b \\
\hline \multirow[t]{2}{*}{ Mean } & $8.34 b$ & $8.96 a$ & $9.15 a$ & $8.51 b$ & & $3.21 \mathrm{~b}$ & $3.41 \mathrm{a}$ & $3.74 a$ & $3.59 a$ & \\
\hline & F -Test & \multicolumn{2}{|c|}{ S.Em \pm} & \multicolumn{2}{|c|}{$\mathrm{CD}$ at $(5 \%)$} & F -Test & \multicolumn{2}{|c|}{ S.Em \pm} & \multicolumn{2}{|c|}{$\mathrm{CD}$ at $(5 \%)$} \\
\hline Factor B & $*$ & \multicolumn{2}{|c|}{0.185} & \multicolumn{2}{|c|}{0.542} & $*$ & \multicolumn{2}{|c|}{0.118} & \multicolumn{2}{|c|}{0.345} \\
\hline Factor $\mathbf{F}$ & $*$ & \multicolumn{2}{|c|}{0.185} & \multicolumn{2}{|c|}{0.542} & $*$ & \multicolumn{2}{|c|}{0.118} & \multicolumn{2}{|c|}{0.345} \\
\hline $\mathbf{B} \times \mathbf{F}$ & $*$ & \multicolumn{2}{|c|}{0.370} & \multicolumn{2}{|c|}{1.085} & $*$ & \multicolumn{2}{|c|}{0.236} & \multicolumn{2}{|c|}{0.691} \\
\hline
\end{tabular}

$\mathrm{B}_{1}$ - Paclobutrazol, $\mathrm{B}_{2}$ - NAA and $\mathrm{B}_{3}$ - Salicylic acid

$\mathrm{F}_{1}$ - Spermidine, $\mathrm{F}_{2}$ - Boron and $\mathrm{F}_{3}$ - CPPU.

Figures with same alphabets did not differ significantly.

** Significant at $(\mathrm{p}=0.01 \mathrm{LOS}), \quad *$ Significant at $(\mathrm{p}=0.05$ LOS $)$, NS- Non Significant.

Values were compared with respective C.D values 
Table.3 Effect of flower enhancing plant bio regulators and fruit set improving chemicals on number of fruits per tree of mango cv. Banganpalli

\begin{tabular}{|c|c|c|c|c|c|}
\hline \multirow[t]{2}{*}{ Treatment } & \multicolumn{5}{|c|}{ Number of fruits per tree } \\
\hline & $\mathrm{B}_{1}-\mathrm{PBZ}$ & $\mathbf{B}_{2}$-NAA & $\mathbf{B}_{3}-\mathbf{S A}$ & B $_{0}$ - Control & Mean \\
\hline$F_{1}-$ Spermidine & $200.00 \mathrm{a}$ & $202.66 \mathrm{a}$ & $136.00 \mathrm{c}$ & $146.66 \mathrm{c}$ & 171.33a \\
\hline$F_{2}-$ Boron & $198.66 a$ & $165.33 b$ & $131.00 \mathrm{c}$ & $133.00 \mathrm{c}$ & $156.99 b$ \\
\hline$F_{3}-\mathbf{C P P U}$ & $172.00 \mathrm{~b}$ & $160.66 b$ & $147.00 \mathrm{c}$ & $145.33 \mathrm{c}$ & $156.24 b$ \\
\hline$F_{0}-$ Control & $158.00 \mathrm{~b}$ & $149.66 b$ & $136.66 c$ & $148.33 b$ & 148.16b \\
\hline \multirow[t]{2}{*}{ Mean } & 182.16a & 169.57b & $137.66 \mathrm{c}$ & $143.33 c$ & \\
\hline & \multicolumn{2}{|c|}{ F -Test } & S.Em \pm & \multicolumn{2}{|c|}{ CD at $(5 \%)$} \\
\hline Factor B & \multicolumn{2}{|c|}{ * } & 4.155 & \multicolumn{2}{|c|}{12.188} \\
\hline Factor $\mathbf{F}$ & \multicolumn{2}{|c|}{ * } & 4.155 & \multicolumn{2}{|c|}{12.188} \\
\hline $\mathbf{B} \times \mathbf{F}$ & \multicolumn{2}{|c|}{ * } & 8.311 & \multicolumn{2}{|c|}{24.376} \\
\hline
\end{tabular}

Figures with same alphabets did not differ significantly.

** Significant at ( $\mathrm{p}=0.01 \mathrm{LOS}),{ }^{*}$ Significant at $(\mathrm{p}=0.05 \mathrm{LOS}), \quad$ NS- Non Significant.

Values were compared with respective C.D values

Table.4 Effect of flower enhancing plant growth regulators and fruit set improving chemicals on time taken for $50 \%$ flowering from panicle initiation of mango cv. Banganpalli

\begin{tabular}{|c|c|c|c|c|c|}
\hline \multirow[t]{2}{*}{ Treatment } & \multicolumn{5}{|c|}{ Fruit weight (gm) } \\
\hline & $\mathbf{B}_{1}-\mathbf{P B Z}$ & $\mathbf{B}_{2}$-NAA & $\mathbf{B}_{3^{-}}-\mathbf{S A}$ & $B_{0}$ - Control & Mean \\
\hline$F_{1}$ - Spermidine & $319.91 \mathrm{c}$ & $331.25 b$ & $355.16 \mathrm{a}$ & $312.08 \mathrm{c}$ & $329.60 \mathrm{~b}$ \\
\hline$F_{2}$ - Boron & $300.08 \mathrm{~d}$ & $325.08 \mathrm{c}$ & $366.00 \mathrm{a}$ & $350.33 a$ & 335.37a \\
\hline$F_{3}-\mathbf{C P P U}$ & $362.41 \mathrm{a}$ & $347.83 \mathrm{a}$ & $317.08 \mathrm{c}$ & $345.00 \mathrm{~b}$ & 343.08a \\
\hline$F_{0}$ - Control & $325.91 \mathrm{c}$ & $303.68 d$ & $352.75 \mathrm{a}$ & $309.25 \mathrm{c}$ & $322.89 b$ \\
\hline \multirow{2}{*}{ Mean } & 327.07b & $326.96 \mathrm{~b}$ & 347.74a & 329.16b & \\
\hline & \multicolumn{2}{|c|}{ F - Test } & S.Em \pm & \multicolumn{2}{|c|}{ CD at $(5 \%)$} \\
\hline Factor B & \multicolumn{2}{|c|}{$*$} & 3.170 & \multicolumn{2}{|c|}{9.299} \\
\hline Factor $\mathbf{F}$ & \multicolumn{2}{|c|}{ * } & 3.170 & \multicolumn{2}{|c|}{9.299} \\
\hline $\mathbf{B} \times \mathbf{F}$ & \multicolumn{2}{|c|}{ * } & 6.341 & \multicolumn{2}{|c|}{18.599} \\
\hline
\end{tabular}

Figures with same alphabets did not differ significantly.

** Significant at $(\mathrm{p}=0.01 \mathrm{LOS}), *$ Significant at $(\mathrm{p}=0.05 \mathrm{LOS})$, NS- Non Significant.

Values were compared with respective C.D values

Table.5 Effect of flower enhancing plant bio regulators and fruit set improving chemicals on yield (kg/tree) of mango cv. Banganpalli

\begin{tabular}{|c|c|c|c|c|c|}
\hline \multirow[t]{2}{*}{ Treatment } & \multicolumn{5}{|c|}{ Yield (kg/tree) } \\
\hline & $\mathbf{B}_{1}-\mathbf{P B Z}$ & $\mathbf{B}_{2}$-NAA & $\mathbf{B}_{\mathbf{3}}-\mathbf{S A}$ & $\mathbf{B}_{0}$ - Control & Mean \\
\hline$F_{1}$ - Spermidine & $63.81 \mathrm{a}$ & $66.74 a$ & $48.03 \mathrm{c}$ & $45.64 \mathrm{c}$ & $56.05 a$ \\
\hline$F_{2}-$ Boron & $59.45 \mathrm{a}$ & $54.04 \mathrm{~b}$ & $47.95 \mathrm{c}$ & $46.54 \mathrm{c}$ & $51.99 b$ \\
\hline$F_{3}-\mathbf{C P P U}$ & $62.38 \mathrm{a}$ & $55.61 \mathrm{~b}$ & $46.62 \mathrm{c}$ & $50.11 \mathrm{~b}$ & 53.68a \\
\hline$F_{0}$ - Control & $51.38 \mathrm{~b}$ & $45.44 c$ & $48.34 \mathrm{~b}$ & $45.08 \mathrm{c}$ & $47.56 c$ \\
\hline \multirow[t]{2}{*}{ Mean } & 59.25a & 55.45a & $47.73 b$ & $46.84 b$ & \\
\hline & \multicolumn{2}{|c|}{ F -Test } & S.Em \pm & \multicolumn{2}{|c|}{ CD at $(5 \%)$} \\
\hline Factor B & \multicolumn{2}{|c|}{ * } & 1.325 & \multicolumn{2}{|c|}{3.886} \\
\hline Factor $\mathbf{F}$ & \multicolumn{2}{|c|}{$*$} & 1.325 & \multicolumn{2}{|c|}{3.886} \\
\hline $\mathbf{B} \times \mathbf{F}$ & \multicolumn{2}{|c|}{ * } & 2.650 & \multicolumn{2}{|c|}{7.773} \\
\hline
\end{tabular}

Figures with same alphabets did not differ significantly.

** Significant at $(\mathrm{p}=0.01 \mathrm{LOS}),{ }^{*}$ Significant at $(\mathrm{p}=0.05 \mathrm{LOS}), \quad$ NS- Non Significant.

Values were compared with respective C.D values 
Table.6 Effect of flower enhancing plant bio regulators and fruit set improving chemicals on benefit cost ratio of mango cv. Banganpalli

\begin{tabular}{|c|c|c|c|c|c|}
\hline Treatment & \multicolumn{5}{|c|}{ Benefit : Cost } \\
\hline & B $_{\mathbf{1}}$ - PBZ & B $_{\mathbf{2}}$-NAA & B $_{\mathbf{3}}$ - SA & B $_{\mathbf{0}}$ - Control & Mean \\
\hline F $_{\mathbf{1}}$ - Spermidine & 6.44 & 8.69 & 5.98 & 5.66 & $\mathbf{6 . 6 9}$ \\
\hline F $_{\mathbf{2}}$ - Boron & 6.17 & 7.19 & 6.27 & 6.09 & $\mathbf{6 . 4 3}$ \\
\hline F $_{\mathbf{3}}$ - CPPU & 3.19 & 3.18 & 2.50 & 2.77 & $\mathbf{2 . 9 1}$ \\
\hline F $_{\mathbf{0}}$ - Control & 5.30 & 6.06 & 6.52 & 6.04 & $\mathbf{5 . 9 8}$ \\
\hline Mean & $\mathbf{5 . 2 7}$ & $\mathbf{6 . 2 8}$ & $\mathbf{5 . 3 1}$ & $\mathbf{5 . 1 4}$ & \\
\hline
\end{tabular}

Market price of fruits $=$ Rs 60 per kg

Basic cost of Chemicals:

Chemical Rs.

$\mathrm{B}_{1}$ - Paclobutrazol $\quad 4,460 /$ lit

$\mathrm{B}_{2}$ - NAA $\quad 2,500 / \mathrm{Kg}$

$\mathrm{B}_{3}-\mathrm{SA} \quad 1498 / \mathrm{Kg}$

$\mathrm{F}_{1}$ - Spermidine $\quad 1850 / \mathrm{gm}$

$\mathrm{F}_{2}$ - Boron 650/Kg

$\mathrm{F}_{3^{-}} \mathrm{CPPU} \quad 4120 / \mathrm{gm}$

Table.7 Effect of flower enhancing plant bio regulators and fruit set improving chemicals on per cent increase in yield and benefit cost ratio of mango cv. Banganpalli

\begin{tabular}{|c|l|c|c|c|}
\hline S.No & \multicolumn{1}{|c|}{ Treatment } & Yield (kg.tree-1) & $\begin{array}{c}\text { \% of yield } \\
\text { increase over } \\
\text { the control }\end{array}$ & B: C ratio \\
\hline $\mathbf{1}$ & Paclobutrazol + Spermidine & $63.81 \mathrm{a}$ & 41.54 & 6.44 \\
\hline $\mathbf{2}$ & Paclobutrazol + Boron & $59.45 \mathrm{a}$ & 31.87 & 6.17 \\
\hline $\mathbf{3}$ & Paclobutrazol + CPPU & $62.38 \mathrm{a}$ & 38.37 & 3.19 \\
\hline $\mathbf{4}$ & Paclobutrazol alone & $51.38 \mathrm{~b}$ & 13.97 & 5.30 \\
\hline $\mathbf{5}$ & NAA + Spermidine & $66.74 \mathrm{a}$ & 48.04 & 8.69 \\
\hline $\mathbf{6}$ & NAA+ Boron & $54.04 \mathrm{c}$ & 19.87 & 7.19 \\
\hline $\mathbf{7}$ & NAA+ CPPU & $55.61 \mathrm{~b}$ & 23.35 & 3.18 \\
\hline $\mathbf{8}$ & NAA alone & $45.44 \mathrm{c}$ & 0.79 & 6.06 \\
\hline $\mathbf{9}$ & SA+ Spermidine & $48.03 \mathrm{c}$ & 6.54 & 5.98 \\
\hline $\mathbf{1 0}$ & SA+ Boron & $47.95 \mathrm{c}$ & 6.36 & 6.27 \\
\hline $\mathbf{1 1}$ & SA+CPPU & $46.22 \mathrm{c}$ & 2.52 & 2.50 \\
\hline $\mathbf{1 2}$ & SA alone & $48.34 \mathrm{~b}$ & 7.23 & 6.52 \\
\hline $\mathbf{1 3}$ & Spermidine alone & $45.64 \mathrm{c}$ & 1.24 & 5.66 \\
\hline $\mathbf{1 4}$ & Boron alone & $46.54 \mathrm{c}$ & 3.23 & 6.09 \\
\hline $\mathbf{1 5}$ & CPPU alone & $50.11 \mathrm{~b}$ & 11.15 & 2.77 \\
\hline $\mathbf{1 6}$ & Absolute control & $45.08 \mathrm{c}$ & 0 & 6.04 \\
\hline & $\quad$ F test & $*$ & & \\
\hline & SEM & 2.650 & & \\
\hline & CD & 7.773 & & \\
\hline
\end{tabular}


Fruit set improving chemical treatments had significant influence on yield per tree. Maximum yield was recorded in application of spermidine $\left(\mathrm{F}_{1}\right)(56.05)$, which was at par with application of CPPU $\left(\mathrm{F}_{3}\right) \quad$ (53.68) followed by application of boron $\left(\mathrm{F}_{2}\right)(51.99)$. Minimum yield was recorded in untreated control $\left(\mathrm{F}_{0}\right)$ (47.56). Spermidine significantly increased the yield per tree compare to control and other treatments. Spermidine effectively increased fruit set per panicle (Table 2) and number of fruits per tree (Table 3) compared to control which might have ultimately increased the yield under present investigation. Similar increase in yield with spermidine was earlier reported by Ravi venkanna babu et al., (2016) in mango cv. Kesar and Dutta et al., (2018) in Himsagar mango.

There is significant difference in yield $\left(\mathrm{kg} . \mathrm{tree}^{-1}\right.$ ) among the interaction between flower enhancing plant bio regulators and fruit set improving chemicals. Maximum yield was recorded in application of NAA along with spermidine $\left(\mathrm{B}_{2} \mathrm{~F}_{1}\right)$ (66.74), which was on par with application of paclobutrazol along with spermidine $\left(\mathrm{B}_{1} \mathrm{~F}_{1}\right) \quad(63.81)$, paclobutrazol along with $\mathrm{CPPU}\left(\mathrm{B}_{1} \mathrm{~F}_{3}\right)$ (62.38) and paclobutrazol along with boron $\left(\mathrm{B}_{1} \mathrm{~F}_{2}\right)$ (59.45). Minimum yield was recorded in untreated control $\left(\mathrm{B}_{0} \mathrm{~F}_{0}\right)$ (45.08). NAA along with spermidine synergistically increase the yield per tree compared to their individual treatments and other treatments. As earlier discussed NAA was found to be responsible for increase in per cent flowering (Table 1) and both NAA and Spermidine are responsible for increase in fruit set per panicle (Table 2) and number of fruits per tree (Table 3). Hence, because of their both yield improving properties might be responsible for increase in yield per tree synergistically compare to their individual application. Similar synergistic increase in yield was earlier reported by Sanna et al., (2005)
Sucrose along with potassium citrate applied mango trees and Vijay Krishna et al., (2012) Paclobutrazol along with spermidine in mango cv. Banganpalli.

The benefit cost ratio of mango cv. Banganpalli sprayed with different flower enhancing plant bio regulators and fruit set improving chemicals are presented in the table 6. Among the flower enhancing plant bio regulator treatments the highest benefit cost ratio was recorded with application of NAA $\left(\mathrm{B}_{2}\right)$ (6.28), lowest benefit cost ratio was recorded in untreated control $\left(\mathrm{B}_{0}\right)(5.14)$. This cost benefit analysis results were due to the low chemical cost per $\mathrm{kg}$ (or) lit, further less dosage of NAA compare to Paclobutrazol and higher yield per tree compare to SA (Table 6).

Among the fruit set improving chemical treatments the highest benefit cost ratio was recorded with application of spermidine $\left(\mathrm{F}_{1}\right)$ (6.69), lowest benefit cost ratio was recorded with application of CPPU $\left(\mathrm{F}_{3}\right)(2.91)$. This may be due to low chemical cost per unit of spermidine compares to CPPU. Among the interactions highest benefit cost ratio was recorded with application of NAA along with spermidine $\left(\mathrm{B}_{2} \mathrm{~F}_{1}\right)$ (8.69), followed by spraying of NAA along with boron $\left(\mathrm{B}_{2} \mathrm{~F}_{2}\right)$ (7.19) and Paclobutrazol along with spermidine application $\left(\mathrm{B}_{1} \mathrm{~F}_{1}\right)(6.44)$. Lowest benefit cost ratio was recorded in application of salicylic acid along with $\mathrm{CPPU}\left(\mathrm{B}_{3} \mathrm{~F}_{3}\right)$ (2.50). NAA along with spermidine interaction treatment resulted in maximum benefit cost ratio compare to control and other treatments. This may be due to chemical cost per $\mathrm{kg}$ (or) lit was lesser compare to other chemicals which were used in interactions.

\section{Per cent increase in yield}

The effect of combination of flowering enhancing plant bio regulators and fruit set 
improving chemical on per cent increase in yield over control along with benefit cost ratio was depicted in table 7. Among the plant bio regulators, Paclobutrazol application alone has increased in the yield up to $13.97 \%$ over control. However, NAA spray alone was least effective in improving the yield of mango over control. Among the fruit set improving chemicals highest per cent increase in yield over control was recorded in spraying of CPPU alone (11.15\%). Spermidine alone was least effective in increasing the yield over control. Among the combination, maximum increase in yield over control was recorded in NAA + spermidine (48.04\%), paclobutrazol + spermidine (41.54 \%), paclobutrazol + CPPU (38.37\%).

\section{References}

Abdel -Razek, E., Abd-Allah, A.S.E., and Saleh, M.M.S. 2013. Foliar Spray of Some Nutrient Elements and Antioxidants for Improving Yield and Fruit Quality of Hindi Mango Trees. Middle-East Journal of Scientific Research. 14 (10): 1257-1262.

Abdel-Rhman, I.E., Eman, I, El-Amary., and Amin, M.G.E. 2017. Effect of Foliar Sprays by GA3, NAA and Algae Extract on Vegetative Growth, Yield, Fruit Quality and Fruit Retention Percentage of Mango cv. Hindi under Newly Reclaimed Soils conditions. Current Science International. 6(3): 578-588.

Apelbaum, A., Burgoon, A.C., Andrew, J.D., Liberman, M., Ben-Arie, R., and Matto, A.K. 1981. Polyamines inhibit biosynthesis of ethylene in higher plant tissue and fruit protoplast. Plant Physiol. 68: 453-456.

Ashok Kumar, M., and Reddy, Y. N. 2007. Effect of calcium nitrate and salicylic acid sprays at flowering on transduction of flowering in mango cv. Baneshan. Crop Research (Hisar) 34(1-3):146-148.

Babul sarker, C., Mohammed, A., Rahim., and Dogulas, D. 2016. Combined effect of fertilizers, irrigation, and Paclobutrazol on yield and fruit quality of mango. Horticultarae.14(2):1-10.
Baiea, M.H.M., El-Badawy, H.E.M., and ElGioushy, S.F. 2015. Effect of Potassium, Zinc and Boron on Growth, Yield and Fruit Quality of Keitt Mango Trees. Research Journal of Pharmaceutical, Biological and Chemical Sciences. 6(4): 800-812.

Bhagwan, A., Vanajalatha, K., Prabhakar Reddy, I., Sarkar, S. K., and Girwani, A. 2011. Standardization of Dosage and Time of Soil Application of Cultar on Flowering and Yield of Mango cv. Banganpalli. Presented in Global Conference on Augmenting Production and Utilization of Mango: Biotic and Abiotic Stresses. 2124th June, 2011 at Lucknow.

Bhagwan, A., Vijaya Krishna., and Rajkumar, M. 2014. Synergestic effects of plant growth regulators and fruit set improving chemicals on flowering, fruit set and yield of mango cv. banganpalli. National Seminar-cum-Workshop on Physiology of Flowering in Perennial Fruit Crops. CISH, Lucknow 210-228.

Bramhachari, V.S., Mandal, A.K,. Kumar, R., Rani, R., and Kumar, R. 1996. Effect of growth substances on flowering and fruiting characters of Sardar guava. Hort. J. 9(1):1-7.

Brown, K.M. 1997. Ethylene and abscission. Physiol. Plant. 100: 567-576.

*Crisosto, C.H. 1988. Putrescine influences ovule senescence, fertilization time, and fruit set in 'Comice' pear. J. Am. Soc. Hort. Sci. 113: 708-712.

Davenport, T. L. 2003. Management of flowering in three tropical and subtropical fruit tree species. HortScience 38:1331-1335.

Davenport, T. L. 2007. Reproductive physiology of mango. Brazilian journal of plant physiology.19(4): 363-376.

Dutta, P., Talang, H.D., and Mukhim, C. 2018. Improved fruit retention, yield and fruit quality in mango cv. himsagar with exogenous application of polyamines. International Journal of Agriculture Sciences. 10 (7): 5782-5784.

Faissal Ahmed, F., Mohamed K.K., and Hamdy Ibrahim, I.M. 2014. The Synergistic Effects of Using Plant Extracts and Salicylic Acid on Yield and Fruit Quality of Keitte Mango Trees. Stem cell. 5(2): 30-39. 
Flaishman, M.A., Shargal, A., and Stern, R.A. 2001. The synthetic cytokinin CPPU increases fruit size and yield of spadona and costia pear. J.Hortic. Sci. Biotechnol.76:145-149.

Gattass, H.R., Essa, A.A, Hend., A, Marzouk, and Safaa El- Nawam, M. 2018. Effect of Application of Some Growth Regulators and $\mathrm{CaCl} 2$ on Fruit Drop, Yield and Fruit Quality of Keitt Mango Trees. Assiut J. Agric. Sci. 49(1): 79-95.

Hayat, S., and Ahmad, A. 2007. Salicylic Acid: a Plant Hormone. Springer. 401.

*John, P., Elano-Frier, D., Norma, O., MartinzGallardo, A., Vega, O.D.M., Manuel, D., Araiza, S., Elva, R., Barbosa, J., Torres, A., Varga, P., and Borodanenko, A. 2004. The Effect of Exogenous Jasmoic Acid on Induced Resistance and Productivity in Amaranth (Amaranthus hypochondriacus) is Influenced by Environmental Conditions. J. Chem. Ecol. 30:1001-1034.

*Kachru., R.B., Singh, R.N., and Chacko, E.K. 1971. Inhibition of flowering in mango by gibberellic acid. Horticulture Science. 6: 140-141.

Kim, J.G., Takami, Y., Mizagami, T., Beppu, K., Fukuda, T., and Kataoka, I. 2006. CPPU application on size and quality of hardy Kiwifruit. Scientia Hort. 110: 219-222.

Kulkarni, S.S., Patil, S.S., and Magar, S.D. 2017. Effect of plant growth regulators on yield and quality of mango (Mangifera indica L.) cv. Kesha. Journal of Pharmacognosy and Phytochemistry. 6(5): 2309-2313.

Kumar, P., Dube, S.D., and Chauhan V.S. 1999. Effect of salicylic acid on growth, development and some biochemical' aspects of soybean (Glycin max L.). Indian j. Plant Physiol. 4: 327-30.

Mandal, B.K., Rani, R., and Ray, R.N. 2015. Effect of foliar spray of urea and growth regulators on marketable yield and quality of mango cv. "Amrapali". International Journal of Agriculture Sciences. 7(7): 554558.

Merwad, M.A., Eisa, R.A., and Saleh, M.M.S. 2016. The beneficial effect of NAA, Zn, Ca and $\mathrm{B}$ on fruiting, yield and fruit quality of Alphonso mango trees. International Journal of ChemTech Research. 9(3):147-
157.

Moawad M.A., Mohamed Sayed, A. El., and Hamdy Abd El- Wahab, A. M. 2015. Response of Succary Mango Trees to Foliar Application of Silicon and Boron. World Rural Observations. 7(2): 93-98.

Mok, D.W.S., and Mok, M.C. 2001. Cytokinin metabolism and action. Annu. Rev. Plant. Biol. 52: 89-118.

*Moti Singh, A.S., Chaudhary, A.S., and Prasad, M. 1987. A note on the effect of some plant regulators on fruit retention in mango (Mangifera indica L). Haryana J. Hort. Sci. 15 (3/4): 221.

Muhammad, N., muhammad faqeer, saeed ahmad, Mueen alam khan, moazzam jamil, and Muhammad naveed aslam. 2010. Paclobutrazol Soil Drenching Suppresses Vegetative Growth, Reduces Malformation, and Increases Production in Mango. International Journal of Fruit Science. 10:431-440.

NHB. (National Horticulture Board), 2017. Indian Horticulture Database-2017. Ministry of Agriculture, Government of India 85, Institutional Area, Sector-18, Gurgaon 122 015. Website: www.nhb.gov.in.

Panse, V.G., and Sukhatme, P.V. 1985. Statistical Methods for Agricultural Workers.4th Ed. I.C.A.R., New Delhi. pp.58-152.

Ponce, M.T., Guinazu, M., and Tizio, R. 2002. Effect of putrescine on embryo development in the stenospermocarpic grape cvs Emperatriz and Fantasy. Vitis. 41: 53-54.

Pujari, K.H., Malshe, A.V., Zagade, V.V., and Shedge, M.S. 2016. Effect of swell (CPPU) on fruit retention, fruit quality and yield of "alphonso" mango. Plant Archives. 16(2): 649-653.

Quinlin, J.D., and Richardson, P.J. 1984. Effect of Paclobutrazol on apple shoot growth. Acta Horticulturae. 146:105-110.

Raj Kumar, M., Reddy, Y. N., Chandrasekhar, R., and Srihari, D. 2006. Effect of calcium and plant growth regulators on flowering and yield of mango (Mangifera indica L.) cv. Baneshan. Journal of Research ANGRAU 34 (1):21-25.

Raj Kumar, M., Reddy, Y. N., Chandrasekhar, R., and Srihari, D. 2007. Effect of pruning, 
paclobutrazol and chemicals on the induction of flowering on new laterals in mango (Mangifera indica L.) cv. Baneshan. Journal of Research ANGRAU 35(1): 2226.

Rajan, S., Divya Tiwari, Singh, V.K., Pooja Saxena, Shilpi Singh, Reddy, Y.T.N., Upreti, K.K., Burondkar, M.M., Bhagwan, A., and Richards Kennedy. 2011. Application of extended $\mathrm{BBCH}$ scale for phenological studies in mango (Mangifera indica L.). Journal of Applied Horticulture. 13(2): 108-114.

Ravi Venkanna Babu, M., Ahlawat, T.R., Alka Singh, Ravi Kanth, J., and Narayana Sawamy, G. 2016. Effect of polyamines on fruit retention and yield of mango (mangifera indica L.) cv. Kesar. The bioscan. 11(1): 211-213.

Sankar, C., Saraladevi, D., and Parthiban, S. 2013. Effect of foliar application of micronutrients and sorbitol on fruit quality and leaf nutrient status of mango cv. Alphonso. The Asian Journal Of Horticulture.8(2):714-719.

Sanna, Ebeed, and Abd El-Migeed, M.M.M. 2005. Effect of Spraying Sucrose and Some Nutrient Elements on Fagri Kalan Mango Trees. Journal of Applied Sciencse Research. 1(5): 341-346.

Shurhozenuo Naleo, Akali Sema and Maiti, C.S. 2018. Effect of Plant Growth Regulators and Packaging on Flowering, Fruit Quality and Shelf Life in Mango cv. Amrapali. Journal of Experimental Agriculture International.2(6):1-8.
Singh, J.N., Singh, D.K., and Chakravarthy, D. 1994. Effect of urea and NAA on fruit retention and physico chemical composition of mango cv. Langra. Orissa journal of Horticulture. 22:26-30.

Singh, Z., and Singh, L. 1995. Increased fruit set and retention in mango with exogenous application of polyamines. Journal of Horticultural Sciences. 70: 271-277.

Srilatha, V., and Reddy, Y.T.N. 2015. Pruning and Paclobutrazol induced flowering and changes in phenols and flavonoids of mango cv. Raspuri. Journal of engineering computers and applied sciences. 4(2):4347.

Vijay Krishna, G. 2012. Studies on the effect of plant growth regulators and chemicals on flowering, fruit set and yield of mango cv. Banganpalli. M.Sc. (Hort.) Thesis submitted to Dr.YSR Horticultural University, Rajendranagar, Hyderabad.

Wahdan, M.T., Habib, S.E., Bassal, M.A., and Qaoud, E.M. 2011. Effect of some chemicals on growth, fruiting, yield and fruit quality of "Succary Abiad" mango. Journal of American Science. 7(2):651658.

Wolukau, J.N., Zhang, S.L., Xu, G.H., and Chen, D. 2004. The effect of temperature, polyamines and polyamine synthesis inhibitor on in vitro pollen germination and pollen tube growth of Prunus mume. Sci. Hort. 99: 289-299.

\section{How to cite this article:}

Vijay Krishna, G., A. Bhagwan, A. Kiran Kumar, A. Girwani, M. Sreedhar, S. Narendar Reddy and Hanuman Nayak, M. 2020. Plant Bio regulators and Chemicals Exogenous Application Impact on Flowering and Yield Attributes of Mango (Mangifera indica L) cv. Banganpalli. Int.J.Curr.Microbiol.App.Sci. 9(07): 3325-3338. doi: https://doi.org/10.20546/ijcmas.2020.907.389 